\title{
The Importance of User Experience Analysis in the Design of an Education Information System Application
}

\author{
Dizyi Orlando Putra ${ }^{1}$, Agus Setiawan²*
}

\author{
${ }^{1}$ Student of Informatics Engineering Department, Universitas Muhammadiyah Magelang, Indonesia \\ ${ }^{2}$ Department of Informatics Engineering, Universitas Muhammadiyah Magelang, Indonesia \\ *Corresponding author. Email: setiawan@ummgl.ac.id
}

\begin{abstract}
One of the main factors in developing a website is the ease of use in carrying out the purpose of the website. Without proper design analysis, of course, website utilization cannot be optimized. Often websites that are used by users are considered to be very complicated and not user friendly so that sometimes the user moves or is reluctant to open the website. The purpose of this research is to examine the importance of user experience factors on the education information system application, considering that information technology has developed and can be used by all fields, including education. This study utilizes data collection methods and literature studies by linking literature to one another to analyze user experience in the design of an information system application in the Field of Education going forward. The results show in general that the interface design to achieve ease of use (usability) in information systems in the field of education also needs to put the user experience factor in its studies, even though users are educated people, but these educated people have strong idealism.
\end{abstract}

Keywords: usability, user experience, information systems, education information system applications

\section{INTRODUCTION}

Information Technology is a way of combining computers with communication lines that carry data, voice, and video. Information technology is a way that can help produce and manipulate, store, communicate, and or convey information [1]. The development of information technology is changing very fast, starting from the life that requires the technology to enter into basic needs and change patterns of life. As information and communication technology is developing more rapidly, now, communication and information exchange can be done using the internet [2]. World internet users continue to increase from year to year, until this year, a total of 4.3 billion of the total population of 7.6 billion [3]. The internet provides access to information exchange services from millions of users throughout the world. Information exchange is utilized by various fields, such as business, academia, government, organizations [4]. Factors that influence or support the realization of quality learning processes in an effort to achieve educational goals, one of which is the use or utilization of information and communication technology in the education and learning process [5] [6]. The website is still considered as a supporting facility. However, many websites are not well managed and not developed in accordance with the changing times and targets of users who will use the website later [7]. The usability measurement of an interface is needed to determine the success of user understanding.

The website is a web-based technology site that allows users to surf (browse) in cyberspace. The website is still considered as a supporting facility. However, many websites are not well managed and not developed in accordance with the changing times and targets of users who will use the website later [7].

The user interface that is too complex actually makes users have difficulty in using, and of course, errors can occur in use. [8] According to research conducted by User Interface Engineering, Inc., it is known that $60 \%$ of the time is wasted because people cannot find the information they want to get and this impact on decreasing productivity and increasing frustration [9]. Measurement of the success of the implementation of a system is carried out to determine the extent of the user's ability to use the system so that the objectives of the use of the system can be achieved. The results of the measurement empirically describe user satisfaction with the system [10].

Usability measurement is done by using a series of data processing related to effectiveness, efficiency, and satisfaction in the use of an information system [10] - [11]. One of the measurement packages that can be used to measure usability is USE because it can cover three dimensions of usability measurement according to ISO, namely efficiency, effectiveness, and satisfaction [10][12]. The design of the current interface cannot be separated from user factors; namely humans, humans have different backgrounds - so that the human factor becomes the key to success in implementing a computer-based system. This paper aims to form the relationship between website development and user experience considerations in information system design in Education.

\section{METHOD}

The method used by researchers in this paper is to use literature studies and link literary studies with one another 
to analyze the importance of User Experience in the design of an Information System Application in the Field of Education now and in the future.

\section{RESULTS AND DISCUSSION}

\subsection{Website development based on version}

The website, like other technologies, is experiencing indirect development as sophisticated as it is today. Next is the development of the website from the initial version to the current version.

\subsubsection{Web 1.0}

a. Web pages are static, where the website is only "readonly" so that one-way communication occurs.

b. Readers can only receive information without participating in providing information.

c. The use of frameset, which is the display of several web pages in one window.

d. The use of HTML tags such as $<$ blink $>$ and $<$ marquee $>$. The existence of online guest book features.

e. The use of buttons with GIF format, usually $88 \times 31$ for product promotion

\subsubsection{Web 2.0}

a. Web users can change the contents of web pages, as in Wikipedia (the previous example).

b. The use of web pages to connect with other users, such as the booming Facebook or MySpace site because users are easy to establish friendships with colleagues, even with old friends who have not been found for a long time.

c. Share content that is fast and efficient, like YouTube, where members can make videos and upload them, and then other people can see the video in a relatively quick time after uploading videos (can be less than 1 hour).

d. A new way to get information, which is Real Simple Syndication (RSS). By using RSS, users can receive notifications when a web page is updated.

e. Internet connection is not limited through computers, but can also be through other devices, such as cellular phones.

\subsubsection{Web 3.0}

a. The target is lodging, transportation, and the like. By using web technology (search engines), we can find locations, lodging, and transportation that are following our financial condition, of course, as much as possible without reducing our comfort in recreation. This information search takes quite a long time, sometimes up to several hours. With the advent of Web 3.0 technology, this search is carried out by the internet itself. The browser analyses the data obtained and displays the results of the analysis to the user. This certainly is more practical.

b. Suppose we enter the keyword "Jupiter" in search engines, what appears? There are many possibilities, for example, an article about a planet called Jupiter or one of the products of motor vehicles. Search engines only display a list of websites that contain these keywords but do not know whether the search results are relevant or not to what we want. With Web 3.0, search engines can analyze the context of the keywords we enter, which is about a planet or a motor vehicle.

c. Each user has a unique internet profile based on our habits when accessing the internet. Web 3.0 makes use of this history when we do 'searching'. That is, when two different people searching with the same keywords, the results displayed may be different, according to the recording browsing of each internet user.

\subsection{User Experience in Website Design involvement}

In developing a website, several things need to be considered so that the site can attract the attention of visitors. Especially in modern times like today, where all website developers are competing to provide better user experience, developing a website must meet several elements such as:

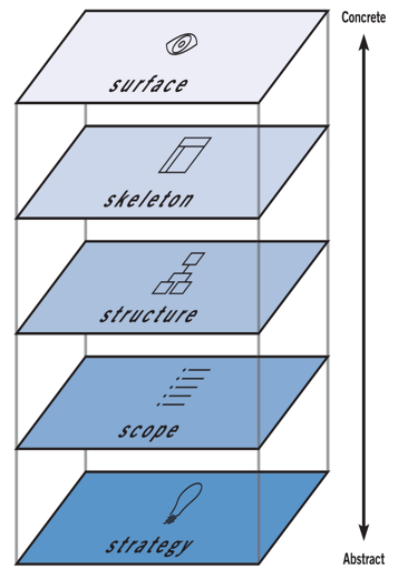

Figure 1 Five planes conceptual framework for user experience [13]

From Figure 1 above, there are surface plane, skeleton plane, structure plane, and strategy plane elements [14]. With a supported interface that is comfortable and easily understood by users. With good website design, not only can attract visitors, but visitors can also respond to the goals of the website and more time-efficient in operating it.

An information system is a system that consists of several sub-systems or components of hardware, software, and Brainware, data, and procedures for running inputs, processes and outputs, storage and control that convert data sources into information [15] 
Whereas simply Information System is a set of sub-systems that are interconnected, gather together, and form a unity, interact with each other and work together between one part with another part with specific ways to perform data processing functions, receive input in the form of data, processing that produces output in the form of information as a basis for decision making [15].

The use of information technology or information systems today has become an unavoidable necessity. According to APJII data, Indonesian internet users in January 2016 have reached 88 million. Undoubtedly the use of this internet would be increased because the government and the private sector continue to provide facilities that increasingly reach new areas in remote areas [7].

The ease of having access to the internet can make humans always depend on an information system. Factors that influence or support the realization of a quality learning process in an effort to achieve educational goals, one of which is the use or utilization of information and communication technology in the education and learning process [5].

The internet is a global network that connects thousands and even millions of computer networks and personal computers, allowing each computer that is connected can contact many computers anytime and from anywhere in the hemisphere to send news, obtain information, or transfer data [5].

The growth rate of users of information technology and the internet shows a number that is so fantastic. Even the internet has become part of the needs of a household and education unit. This phenomenon shows that in the coming year, information technology would master most of the learning patterns of students [5].

The Education Sector would utilize information systems as a strategic way to convey information to students. The development and dependence of the information system would affect the ease of using the information system, and it is necessary to measure the understanding of the information system used to facilitate the delivery of the objectives and contents of the information. Required way to measure the ease of use of the information system.

User Experience or commonly referred to as UX is a person's perception and response resulting from the use and or anticipation of using a product, system or service [14] or more simply User Experience is how you feel about each interaction that you are facing with what lies ahead of You when you use it [16].

To get the user experience factor at an appropriate system interface, a system must have a match between product features and user needs. This then determines that the product is valuable or valuable. Next, if the product is easy to find and easy to use the first time, then the product can make users feel happy when using it. And the last thing, the product must be easy to use to complete or do things that are desired by the user [16]. In conducting the evaluation process must comply with the four elements contained in the picture below. In the picture has the values Value, Usability, Adoptability, Desirability [17]

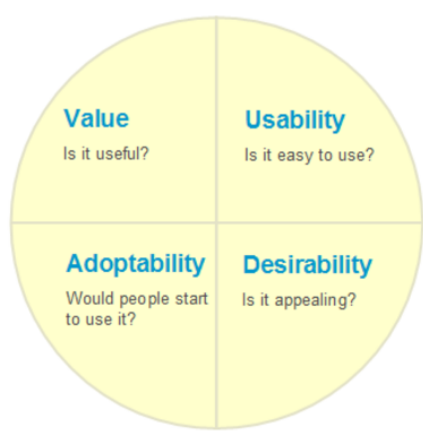

Figure 2 Four elements in user experience

\section{CONCLUSION}

With the development of technology and how to use it, it is expected to provide significant benefits to the world of Education. Education is not always about learning, which requires face-to-face meetings between lecturers and students. The system has shifted slowly with the use of information systems used for teaching and learning activities. But in the process of designing the system, there are still difficulties in the information system user to understand the purpose of the system. An evaluation is needed to reduce the difficulties encountered by the user in understanding the objectives of the system. A good information system is a system that can be easily understood by users of the system.

\section{ACKNOWLEDGMENT}

The author thanks the family for encouraging and encouraging the research process to the process of compiling this article, and not forgetting friends who helped in the research process.

\section{REFERENCES}

[1] R. A. Ryan Prasetyo Adi, M.Akbar, "Sistem Informasi E-Museum Sebagai Media Penyajian Informasi Sistem Informasi Benda-Benda Sejarah Dan Budaya Di Sumatera Selatan," in Universitas Bina Darma, 2016, no. March.

[2] F. T. Talika, "Manfaat Internet Sebagai Media Komunikasi Bagi Remaja Di Desa Air Mangga Kecamatan Laiwui Kabupaten Halmahera Selatan," ejurnal "Acta Diurna," vol. V, no. 1, pp. 1-6, 2016.

[3] S. Kemp, "Digital 2019: Global Internet Use Accelerates - We Are Social," 2019. https://wearesocial.com/blog/2019/01/digital-2019global-internet-use-accelerates (accessed Nov. 05, 2019). 
[11] A. Setiawan, E. U. Artha, E. R. Arumi, Sunarni, A. Primadewi, and S. Nugroho, "Task Analysis of Facebook users on Frequently used Menus," J. Phys. Conf. Ser., vol. 1179, p. 012019, Jul. 2019, doi: $10.1088 / 1742-6596 / 1179 / 1 / 012019$.

[5] M. Tekege, "Pemanfaatan Teknologi Informasi dan Komunikasi dalam Pembelajaran SMA YPPGI Nabire," J. FATEKSA J. Teknol. dan Rekayasa, vol. 2, no. 1, pp. 40-52, 2017, [Online]. Available: https://uswim.ejournal.id/fateksa/article/view/38.

[6] O. D. Ariska, A. Kusyanti, and F. A. Bachtiar, "Evaluasi Kualitas Layanan Website Portal Jurnal Universitas Brawijaya dan Website Student Journal Universitas Brawijaya Menggunakan Metode Webqual 4 . 0 dan IPA (Importance Performance Analysis)," J. Pengemb. Teknol. Inf. dan Ilmu Komput., vol. 2, no. 8, pp. 2595-2603, 2018.

[7] A. Setiawan and R. A. Widyanto, "Evaluasi Website Perguruan Tinggi menggunakan Metode Usability Testing," J. Inform. J. Pengemb. IT, vol. 3, no. 3, pp. 295-299, 2019, doi: 10.30591/jpit.v3i3.912.

[8] Soediono, “Analisis pengaruh,” J. Chem. Inf. Model., vol. 53, p. 160, 1989, doi:

10.1017/CBO9781107415324.004.

[9] I. S. Y. Saputri, M. Fadhli, and I. Surya, "Penerapan Metode UCD (User Centered Design) Pada ECommerce Putri Intan Shop Berbasis Web," Teknol. DAN Sist. Inf., vol. 3, no. 2, pp. 269-278, 2017.

[10] W. A. Kusuma, V. Noviasari, and G. I. Marthasari, "Analisis Usability dalam User Experience pada Sistem KRS Online UMM menggunakan USE Questionnaire," J. Nas. Tek. Elektro dan Teknol. Inf., vol. 5, no. 4, pp. 294-301, 2017, doi: 10.22146/jnteti.v5i4.277.
[12] A. Setiawan and R. Widaryanto, "Mobile CRM student-parent information system," IOP Conf. Ser. Mater. Sci. Eng., vol. 403, p. 012076, Oct. 2018, doi: 10.1088/1757-899X/403/1/012076.

[13] J. J. Garrett, The elements of user experience: usercentred design for the web. New Riders, 2010.

[14] M. B. Wiryawan, “User Experience (Ux) sebagai Bagian dari Pemikiran Desain dalam Pendidikan Tinggi Desain Komunikasi Visual," Humaniora, vol. 2, no. 2, p. 1158, 2011, doi: 10.21512/humaniora.v2i2.3166.

[15] M. Huda, W. W. Winarno, E. T. Lutfi, and S. P. Bangsa, "Evaluasi User Interface Pada Sistem Informasi Akademik Di Stie Putra Bangsa Menggunakan Metode User Centered Systems Design," J. Ekon. Dan Tek. Inform., vol. 5, no. 2, pp. 42-59, 2017.

[16] R. D. Munthe, K. C. Brata, and L. Fanani, "Analisis User Experience Aplikasi Mobile Facebook (Studi Kasus pada Mahasiswa Universitas Brawijaya)," J. Pengemb. Teknol. Inf. dan Ilmu Komput., vol. 2, no. 7, p. 2680, 2018.

[17] F. Y. Guo, "Not Just Usability - The Four Elements of User Experience Usability," 2012. [Online]. Available: http://uxstrategized.com/White_Paper_Four_Elements of_User_Experience.pdf. 